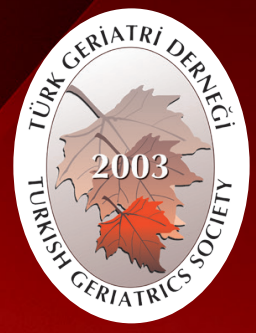

Turkish Journal of Geriatrics

DOI: 10.31086/tjgeri.2019150570

2019;22 (1):32-37

- illknur KAYALI ${ }^{1}$ iD

- Rahşan HABIBOĞLU1 (D)

- İrem SARICANBAZ1 D

- Yıllar LEHIMCIOĞLU1 (D)

\title{
HYPOFRACTIONATED RADIOTHERAPY AND CONCOMITANT TEMOZOLOMIDE FOR HIGH-GRADE GLIAL TUMORS IN ELDERLY PATIENTS
}

\section{Abstract}

Introduction: Glioblastoma is the most common primary tumor in adults and age is a poor prognostic factor. Its main treatment is surgical removal. After surgery, radiotherapy is the mainstay treatment for glioblastoma. The aim of this study was to evaluate the survival and toxicity of short-course radiotherapy (40 Gy in 15 fractions) and temozolomide.

Materials and Method: A total of 22 patients over 65 years received hypofractionated radiotherapy (40 Gy in 15 fractions) and temozolomide ( $75 \mathrm{mg} / \mathrm{m} 2 /$ day).

Results: No grade 3 and 4 leukopenia or thrombocytopenia occurred among the patients. The median survival for patients with grade IV disease (including gliosarcoma) was 7 months [95\% confidence interval $(\mathrm{Cl}), 3.0-10.9$ ] and that of patients with grade III disease was 2 months ( $95 \% \mathrm{Cl}, 0-35.6)$. There was no need to stop or delay the treatment.

Conclusion: Standard and short-course radiotherapy and temozolomide were found to be equally effective to prevent disease progression and salvage treatment. Notably, elderly patients find it difficult to visit a hospital everyday. Moreover, long-term therapies are financially and physically burdensome for them. Besides, comorbidities are seen often in the elderly.

Keywords: Aged; Glioblastoma; Astrocytoma; Radiation Dose Hypofractionation; Radiotherapy

CORRESPONDANCE

ilknur KAYALI

Health Sciences University, Ankara Numune Training and Research Hospital, Department of Radiation Oncology, Ankara, Turkey

Phone: 03125085506

e-mail: ilknuraytas@yahoo.com

Received: 08/11/2018

Accepted: $30 / 01 / 2019$

Health Sciences University, Ankara Numune Training and Research Hospital, Department of Radiation Oncology, Ankara, Turkey

\section{YÜKSEK GRADLI GLIOMU OLAN YAŞLI HASTALARDA EŞ ZAMANLI TEMOZOLAMID VE HIPOFRAKSIYONE RADYOTERAPI}

Öz $_{z}$

Giriş: Glioblastom yetişkinlerde en sık görülen tümördür. İleri yaş kötü prognostic özelliktir. Esas tedavi cerrahi olarak çıkarılmasıdır. Cerrahi sonrası, glioblastom tedavisinde ana rolü radyoterapi üstlenir. Bu çalışmanın amacı kısa kurs radyoterapinin ( 15 fraksiyonda 40 Gy) sağ kalım ve toksisite açısından değerlendirilmesidir.

Gereç ve Yöntem: Altmış beş yaş üstü 22 hastaya hipofraksiyone radyoterapi (15 fraksiyonda $40 \mathrm{~Gy}$ ) ve temozolamid ( $\left.75 \mathrm{mg} / \mathrm{m}^{2} / \mathrm{gün}\right)$ uygulanmıştır.

Bulgular: Hiçbir hastada grad 3 ve 4 lökopeni veya trombositopeni gözlenmemiştir. Medyan sağkalım grad IV (gliosarkom dahil) hastalığı olan hastalarda 7 ay (\%95GA, 3.0-10.9), grad III hastalığı olan hastalarda 2 ay (\%95GA, 0-35.6). Hiçbir hastada tedaviye ara verme veya tedaviyi durdurma gerekliliği oluşmamıştır.

Sonuç: Yaşı kişilerin hergün hastaneye gelmelerinin kolay olmadığı akılda tutulmalıdır. Aynı zamanda uzun süreli tedaviler hem maddi hem de manevi açıdan bu hastalar için yük, sıkıntı ve tehlike barındırı. Tüm bunların yanında yaşlı hastalarda eşlik eden hastalıklar sık görülür. Hastalık progresyonunu ve salvaj tedaviyi önlemek açısından standart ve kısa kurs RT ve TMZ eşit etkinlikte bulunmuştur.

Anahtar sözcükler: Yaşı hasta; Yüksek gradlı glial tümör; Hipofraksiyone radyoterapi; Radyoterapi 


\section{INTRODUCTION}

Glioblastoma (GB) is the most common primary brain tumor in adults. High-grade glial tumors have short survival rates and are among the top five causes of death (1). Despite the progress in treatment, treatment for $\mathrm{GB}$ is still challenging. Most studies have evaluated radiotherapy (RT) and/or chemotherapy doses in GB (WHO grade IV) but not anaplastic tumors (WHO grade III), although they lead to high-grade gliomas (HGG) with GBs.

The incidence of HGG, particularly GB, increases with age (2). The median age at prognosis is approximately 65 years (3), and age is a poor prognostic factor. The main therapy for HGG is surgical removal; however, because of comorbidities, elderly patients are often suboptimally treated (4). After surgery, RT becomes the mainstay treatment for GB.

Stupp et al.proved statistically significant survival benefit with minimal additional toxicity with concurrent RT and chemotherapy (temozolomide, TMZ) $(5,6)$. The randomized EORTC26981/22981$\mathrm{NCIC} \mathrm{CE.3} \mathrm{trial} \mathrm{also} \mathrm{showed} \mathrm{that} \mathrm{adding} \mathrm{TMZ} \mathrm{to}$ $\mathrm{RT}$ improves the median and 2-year survival rates compared to RT alone (7).

As alternative to the 6-week RT and TMZ, short-course treatment can also be effective (3,8-12). The Nordic randomized, phase 3 trial revealed that TMZ and hypofractionated RT should be considered a standard treatment in elderly patients $(8,13)$. Roa et al. demonstrated similar survival benefits with hypofractionated RT, that is, $40 \mathrm{~Gy}$ in 15 fractions over 3 weeks, and TMZ compared to 6-week RT (11).

In our clinic, we have offered hypofractionated RT and TMZ to patients aged more than 65 years since 2012. Therefore, this study aimed to evaluate the survival and toxicity of shortcourse radiotherapy (40 Gy in 15 fractions) and temozolomide.

\section{MATERIALS AND METHOD}

In this retrospective study, we identified 22 patients who received hypofractionated $\mathrm{RT}$ with the total radiation dose divided into large doses, and treatments were given once a day or less often. Hypofractionated RT was given over a shorter time period than the standard RT (40 Gy in 15 fractions, in 3 weeks, which has the same biological effects as the 6-week standard RT) and TMZ. Medical records of these patients who were treated with hypofractionated RT and TMZ between 2012 and 2017 were retrospectively evaluated.

Inclusion criteria were as follows: histologically proven HGG (GB or anaplastic glioma), age $\geq 65$ years, Eastern Cooperative Oncology Group performance status $\leq 2$, no prior RT and/or chemotherapy to head and neck region, adequate bone marrow reserve (hemoglobin $\geq 10 \mathrm{~g} / \mathrm{dL}$, absolute neutrophil count $\geq 1,500 / \mu \mathrm{L}$, and platelet count $\geq 100,000 / \mu \mathrm{L}$ ), normal renal function, and normal hepatic function. Patients were excluded from the study if they were in poor medical condition because of nonmalignant systemic disease or acute infection or if they had any medical condition (physical or mental) that could interfere with the oral administration of TMZ.

All patients were simulated by computed tomography (CT) (GE BrightSpeed) with $0.125 \mathrm{~cm}$ slice thickness, and contoured and planned by Eclipse planning system Aria V11. Thermoplastic masks were used for the immobilization of all patients. The clinical target volume covered the edema, and $1-\mathrm{cm}$ margin was added to form the planning target volume. EORTC (European Organization for Research and Treatment of Cancer) constraints were used to determine the doses for organs at risk. For every patient, the most recent magnetic resonance image was used for fusion with simulation CT. 
Volumetric modulated arc therapy was given by Varian Trilogy model therapy unit (Volume Modulated Arc Therapy, i.e., Rapidarc). The RT dose was 267 cGy/fractions, 15 fractions, total of 4005 cGy, given 5 days a week, for 3 weeks. Patients were given $75 \mathrm{mg} / \mathrm{m}^{2} /$ day of $\mathrm{TMZ}$ concomitantly with RT including weekends (for 7 days a week) in the morning. None of the patients received trimethoprim-sulfamethoxazole.

The Common Terminology Criteria for Adverse Events grading system was used for the assessment of toxicity, and patients were assessed weekly during RT for toxicity. Complete blood counts and blood chemistry were performed weekly during treatment. After RT was completed, TMZ was planned to continue at $150-200 \mathrm{mg} / \mathrm{m}^{2} /$ day for six cycles ( 5 days for every 28 days).Patients were followed up for 3 months. The follow-up assessment included neurological evaluation, cranial magnetic resonance imaging (MRI) (either diffusion or multivoxel spectroscopic MRI), blood count, and blood chemistry.

The protocol was reviewed and approved by the local ethics committee.

Statistical analysis was performed using SPSS (PASW Statistics 18). The main objectives were to evaluate toxicity and overall survival (OS) using Kaplan-Meier analysis. OS was calculated from starting date of RT to the date of death.

\section{RESULTS}

All 22 eligible patients were evaluated for toxicity. The median age was 69 (range, 65-78) years. Of the 22 patients, 14 (64\%) were men and 8 (36\%) were women. Of the patients, $6(27 \%)$ had anaplastic astrocytoma (WHO grade III), 14 (64\%) had GB (WHO grade IV), and 2 (9\%) had gliosarcoma (WHO grade IV). Two patients (9\%) (1 with gliosarcoma and 1 with GB) had multiple lesions. Total excision was performed in $2(2 \%)$ patients, gross total in 5 (23\%), subtotal in 3 (14\%), and biopsy in 12 (54\%).

The Common Terminology Criteria for Adverse Events grading system was used for the assessment of toxicity. The TMZ+RT combination was well tolerated. Although the main side effect was expected to be myelosuppression, during the concomitant RT+TMZ, no grade 3 and 4 leukopenia or thrombocytopenia occurred in patients. Only one patient experienced serious infection and subsequently died of sepsis after 5 months of RT completion. No neurotoxicity was seen. Scalp reactions and hair loss were observed in all patients. Grade 1 (faint erythema or dry desquamation) radiation dermatitis was reported in all patients. Grade 1 nausea (loss of appetite without alteration in eating habits) was seen in $50 \%$ of patients and was medicated. Neither an interruption nor a need to stop was needed for the treatment.

Late neurologic side effects were not assessed because of the short follow-up duration.

SPSS 18 was used for statistical analyses. The median OS was 7 months;6-month, 1-year and 2 -year OS for the whole cohort were 63\%, 40\% and $22 \%$ respectively (fig. 1) The median follow-up for the entire group was 8 (range, 0-58) months. During the analysis period, all patients had died. One patient died of sepsis which occurred after 5 months, and in another one patient, the death cause was not related to malignancy. The median survival for patients with grade IV disease (including gliosarcoma) was7 months [95\% confidence interval (Cl), 3.0-10.9]and 2 months (95\% Cl, 0-35.6) for patients with grade III disease. There was no statistical difference between survival among the patients $(p=0.27)$. 


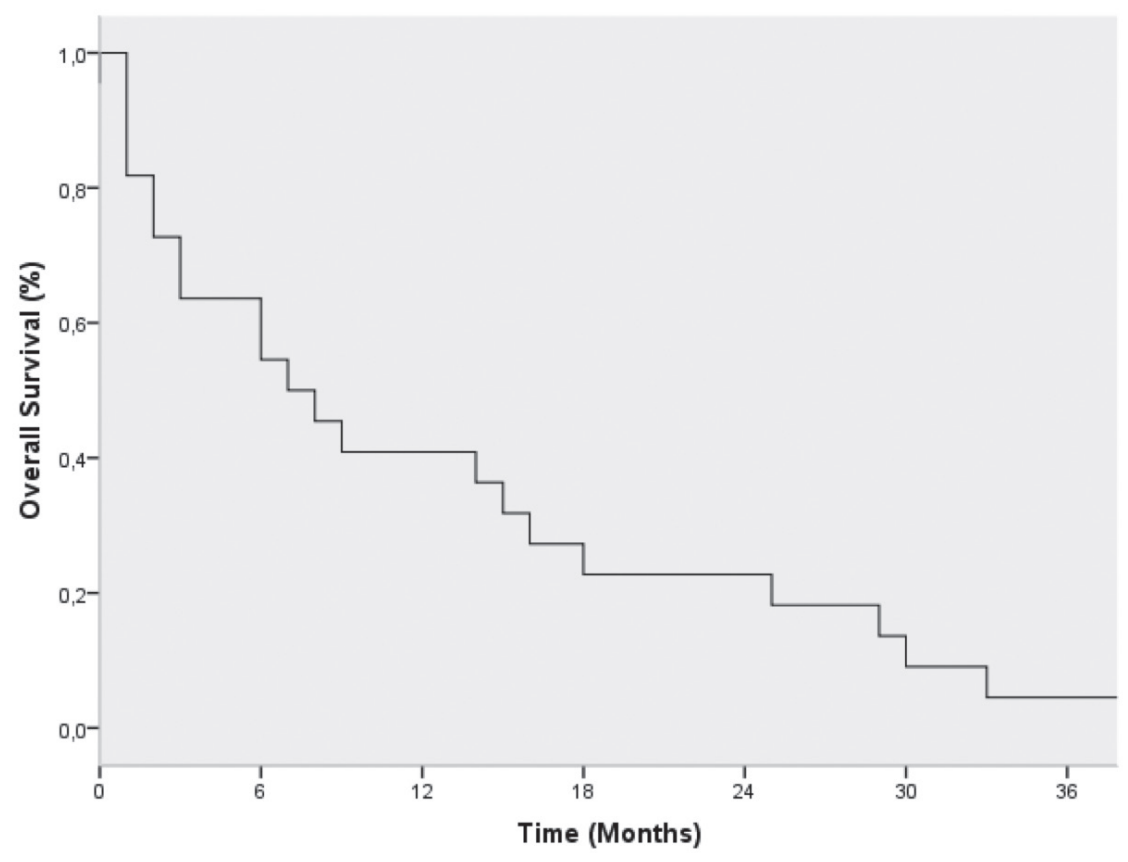

Figure 1. Overall Survival.

According to the extent of surgery, e.g., gross total excision vs others, the median survival was 12 months $(95 \% \mathrm{Cl}, 0-41.6)$ vs 3.4 months $(95 \% \mathrm{Cl}$, $0-12.7)$. Although the extent of surgery was not found to be a statistically significant predictor, there was a tendency for longer survival for gross total excision. There was no difference in survival with respect to sex.

\section{DISCUSSION}

Elderly patients with HGG have short survival time; therefore, undergoing therapies that do not offer longer survival should be avoided (14). RT is well known to prolong survival compared to best supportive management (7). In another study, combined therapy was reported to be beneficial in patients aged 60-70 years (6). The standard 6-week RT can be associated with important risks of morbidity, treatment interruptions, and even treatment cessation (8). When TMZ is combined with RT, the risk for death decreases; therefore, the median OS is prolonged compared to RT alone (10). Numerous studies indicated that almost $50 \%$ of elderly patients may fail to undergo treatment (15). Stephanie et al. reported that treatment interruptions were seen in 6-week RT and TMZ because of toxicities, although the TMZ dose was mostly $50 \mathrm{mg} /$ $\mathrm{m}^{2}(2)$. In our study, we were able to give radiotherapy and $75 \mathrm{mg} / \mathrm{m}^{2} \mathrm{TMZ}$ without any interruption. As short course radiotherapy and $T M Z$ regime was used, the duration for therapy was shortened and there was no need for either interruption or cessation.

The PERNO study identified the groups that will benefit from RT and temozolomide. RT was given either in short course or 6-week course. TMZ was used in both groups. There was no difference in median survival between hypofractionated or fulldose RT groups (4). Roa et al. reported that the median survivals were similar for the short-course 
group (5.6 months) and 6-week group (5.1 months). Moreover, there were no differences in the Karnofsky Performance Status (KPS) scores between the groups both at the first follow-up and over time (11). In another study, the median OS was found to be 11 months (2). The OS rate was $48 \%$ at 1 year and $8 \%$ at 2 years. During the follow-up, all patients had died because of tumor progression. In general, the OS in elderly patients was 4-9 months (2). Similarly, the standard and short-course RT and TMZ were found to be equally effective to avoid disease progression and salvage treatment (5). Similarly, in our study, the median survival was found to be 7 months. The1-year OS was $40 \%$ and the 2 -year OS was $22 \%$.

Quality of life scores for function and symptoms do not differ between short-course RT and shortcourse RT+ TMZ (10).Although postoperative RT and $T M Z$ have been established as the standard treatment for GB (2), optimal treatment of HGG in the elderly is still unclear. After surgery, RT and/ or TMZ demonstrated to prolong survival in most studies (16). For elderly patients with GB, the National Comprehensive Cancer Network guidelines recommend combined RT and TMZ (category 2B). In Uto et al.'s trial, only one patient had experienced grade 4 hematological adverse event, and no grade 3 or higher nonhematological adverse event was found (12). In Greer et al.'s study, hypofractionated RT was well tolerated, in which no RTOG grade 3/4 toxicities was reported (17). Similarly, in our study, any grade3/4toxicity was not noted. It is well known that toxicities (especially grade 3 and grade 4) make differences in quality of life scores. As in our study no grade 3 or grade 4 toxicity was seen, all of the patients have tolerated the treatment.

Among elderly patients ( $\geq 70$ years old) with fairgood performance status (KPS $\geq 50$ ), The ASTRO (American Society for Radiation Oncology) evidencebased clinical practice guideline recommends external beam RT following biopsy or resection, as RT (compared to supportive care alone) improves OS without impairing quality of life or cognition (strong evidence) (18). Among elderly patients, there is no evidence that conventionally fractionated RT (60 Gy in 30 fractions over 6 weeks) is more efficacious than hypofractionated RT (e.g., 40 Gy in 15 fractions over 3 weeks). Compared to conventionally fractionated $\mathrm{RT}$, hypofractionated RT has been associated with superior survival and less corticosteroid requirement (strong evidence) (18).

Moreover, Fabio et al. concluded that if O6methylguanine-DNA-methyltransferase (MGMT) promoter methylation status cannot be tested, combined modality therapy with hypofractionated $\mathrm{RT}$ with concurrent TMZ would be well enough as the initial approach (19).

Our study has some limitations. We were unable to put forth the MGMT status. In addition, the death status was learned from the relatives of the patients, so we were unable to deliver disease-free survivals.

In conclusion, surgical resection should be as wide as it can be. As adjuvant therapy, hypofractionated RT with $T M Z$ is the best treatment choice, particularly if the MGMT promoter methylation status is unknown. Moreover, a short treatment time has numerous advantages besides having survival time comparable to standard treatment. Clinical, social, and financial conditions must be considered when determining the optimal age-specific treatment approach for HGG (15).

In our study we have found that short course radiotherapy with $\mathrm{TMZ}$ can be tolerated by elderly patients and has got similar outcomes as the standart treatment. Notably, elderly patients find it difficult to go to a hospital everyday; besides, relatives are not always willing to take them to a hospital. Further, long-term treatments are financially and physically burdensome for them, and comorbidities are seen often among elder patients.

\section{Conflict of interest}

The authors declare no conflicts of interest associated with this study. 


\section{REFERENCES}

1. BaldwinK. Elderly patients with glioblastoma live longer with chemoradiation using temozolomide [Internet] Available from: https://webcache.g., oogleusercontent.com/search? $q=$ cache: SODwsO0iz4cJ:https://www.asco.org/printpdf/aboutasco/press-center/news-releases/elderly-patientsglioblastoma-live-longer-chemoradiation-using $+\& c d=$ $1 \& \mathrm{hl}=\operatorname{tr} \& \mathrm{ct}=\mathrm{clnk} \& \mathrm{gl}=\mathrm{tr}$. Accessed: 04.10.2018

2. Combs SE, Wagner J, Bischof M, et al. Postoperative treatment of primary glioblastoma multiforme with radiation and concomitanttemozolomide in elderly patients. Int J RadiatOncolBiol Phys 2008;70 (4):98792. (PMID:17967509).

3. NillsArvold ND, ReardonDA.Treatment options and outcomes for glioblastoma in the elderly patient. Clinlnterv Aging 2014;9:357-67. (PMID:24591820).

4. Franceschi E, Depenni R, Paccapelo A, et al. Which elderly newly diagnosed glioblastoma patients can benefit from radiotherapy and temozolomide? A PERNO prospective study. J Neurooncol 2016;128(1):157-162. (PMID:26943851).

5. Minniti G, Scaringi C, Lanzetta G, et al. Standard (60 Gy) or short-course (40 Gy) irradiation plus concomitant and adjuvant temozolomide for elderly patients with glioblastoma: a propensity-matched analysis. Int J RadiatOncolBiol Phys 2015;91(1):109-15. (PMID:25442339).

6. Stupp R, Mason WP, van den Bent MJ, et al.Radiotherapy plus concomitant and adjuvant temozolomide for glioblastoma. $N$ Engl J Med 2005;352:987-96. (PMID:15758009).

7. Gerstein J, Franz K, Steinbach JP, et al.Postoperative radiotherapy and concomitant temozolomide for elderly patients with glioblastoma. RadiotherOncol 2010;97(3):382-6. (PMID:20850883).

8. Malmström A, Grønberg BH, Marosi C, et al. Temozolomide versus standard 6-week radiotherapy versus hypofractionated radiotherapy in patients older than 60 years with glioblastoma: the Nordic randomised, phase 3 trial.Lancet Oncol 2012;13(9):91626. (PMID:22877848).

9. Cao JQ, Fisher BJ, Bauman GS, Megyesi JF, Watling CJ, Macdonald DR. Hypofractionated radiotherapy with or without concurrent temozolomide in elderly patients with glioblastoma multiforme: a review of ten-year single institutional experience.J Neurooncol 2012;107(2):395-405.(PMID:22105851).
10. Perry JR, Laperriere N, O'Callaghan CJ, et al. Shortcourse radiation plus temozolomide in elderly patients with glioblastoma. N Engl J Med 2017;376(11):102737. (PMID:28296618).

11. Roa W, Brasher PM, Bauman $G$, et al. Abbreviated course of radiation therapy in older patients with glioblastoma multiforme: a prospective randomized clinical trial.J ClinOncol 2004;22(9):15838. (PMID:15051755).

12. Uto M, Mizowaki T, Ogura Ket al. Feasibility evaluation of hypofractionated radiotherapy with concurrent temozolomide in elderly patients with glioblastoma. Int J ClinOncol 2016;21(6):1023-9. (PMID:27384182).

13. Okada M, Miyake K, Tamiya T. Glioblastoma treatment in the elderly. Neurol Med Chir (Tokyo) 2017; 57(12):667-76. (PMID:29081442).

14. Malmstrom A, Grønberg BH, Stupp $R$, et al. Glioblastoma (GBM) in elderly patients: A randomized phase III trial comparing survival in patients treated with 6-week radiotherapy (RT) versus hypofractionated RT over 2 weeks versus temozolomide single-agent chemotherapy (TMZ).J ClinOncol2010;28(18_ suppl):LBA2002. (PMID:27937455).

15. Chamberlain MC, Recht LD, Glantz M. Regarding "abbreviated course of radiation therapy in older patients with glioblastoma multiforme: a prospective randomized clinical trial". J ClinOncol 2005;23(7):15878; author reply 1588. (PMID:15735141).

16. Metcalfe E, Karaoglanoglu O, Akyazici E. Radiotherapy with or without temozolomide in elderly patients aged $\geq 70$ years with glioblastoma. ContempOncol (Pozn) 2016;20(3):251-5. (PMID:27647990).

17. Greer L, Pannullo SC, Smith AW, et al. Accelerated hypofractionated radiotherapy in the era of concurrent temozolomide chemotherapy in elderly patients with glioblastoma multiforme. Cureus 2017;9(6):e1388. (PMID:28775928).

18. Cabrera AR, Kirkpatrick JP, Fiveash JB, et al. Radiation therapy for glioblastoma: executive summary of an american society for radiation oncology evidencebased clinical practice guideline. Pract Radiat Oncol 2016;6(4):217-25. (PMID:27211230).

19. de Moraes FY, Laperriere N. Glioblastoma in the elderly: initial management. Chin ClinOncol 2017;6(4):39. (PMID:28841801). 